\title{
Screening of Potential Yeast of Sugar Palm Sap from Several Regions of West, Sumatra to Find Superior Isolate for Support Bioethanol Production
}

\author{
Primadona Raesa Putri, Nurmiati Nurmiati* and Periadnadi Periadnadi
}

\begin{abstract}
Laboratory of Microbiology, Biology Department, Faculty of Mathematics and Natural Sciences, Andalas University, Limau Manis, West Sumatra-25163, Indonesia
\end{abstract}

*Corresponding author

\begin{tabular}{l} 
K e y w o r d s \\
$\begin{array}{l}\text { Yeast, Sugar palm } \\
\text { Sap, West Sumatra, } \\
\text { Fermentative }\end{array}$ \\
\hline Article Info \\
$\begin{array}{l}\text { Accepted: } \\
\text { 20 November } 2019 \\
\text { Available Online: } \\
\text { 10 December } 2019\end{array}$ \\
\hline
\end{tabular}

A B S T R A C T

\begin{abstract}
Yeast is a microorganism that plays an important role and is believed to be the most potential in the fermentation process and produce ethanol. Yeast can be isolated from sources of raw materials, one of which is sugar palm sap which grows quite a lot in several regions of West Sumatra. The purpose of this study was to analyze the proportional existence of yeast sugar palm sap in several regions of West Sumatra, determine the morphological character and fermentative potential of the obtained yeast isolates. In this study, the yeast from fresh sugar palm sap was isolated using a YEA medium by pour plate. The isolates that have been obtained are then morphologically characterized (macroscopic and microscopic). Then the fermentation test was carried out using a Durham tube to determine the fermentative potential of the obtained yeast isolates. The results showed that 11 different yeast isolates were obtained based on morphological characters both macroscopically and microscopically. In the character of fermentative potential, $\mathrm{BTS}_{9}$ isolate is the yeast that has the highest fermentation activity. This indicates that $\mathrm{BTS}_{9}$ isolates have more potential in producing ethanol.
\end{abstract}

\section{Introduction}

Yeast is a microorganism that plays an important role in the fermentation process. Besides having an important role in the fermentation process, yeast is a group of microorganisms that are believed to be the most potential in producing ethanol. This is supported by the statement of Satyanarayana and Kunz (2009) that yeast is one of the microorganisms that play an active role during the fermentation process of alcoholic beverages. In line with the statement of Schneiter (2004), the famous character of yeast is its ability to produce ethanol.

Yeast can be isolated from sugar-based sources, one of which is sap from palm plants that grow in the tropics. Sugar palm plants (Arenga pinnata Merr.) are found in areas with relatively high and even rainfall throughout the year, especially in some areas of West Sumatra. According to Effendi (2010), West Sumatra is one of fourteen 
provinces that are included in the palmproducing region. The estimated total area of palm sugar plantations in West Sumatra Province is 1.830 ha with an estimated sap production of 8.640 L/year and estimated ethanol production of $345.6 \mathrm{~L} /$ year.

Sugar palm sap is known to contain high sugar levels so it is suitable for the growth yeast substrate. Palm juice derived from sugar palm is one of the sources of yeast that can potentially produce abundant ethanol as evidenced by the fast fermented palm sap.

Based on the important role of yeast in the fermentation process and as a producer of ethanol, this study was conducted which aims to find potential yeast isolates, determine the morphological character and fermentative potential characteristics of the obtained yeast isolates.

\section{Materials and Methods}

This study used a survey method that was conducted in several stages: isolation of palm sugar yeast, macroscopic and microscopic characteristics, fermentation intensity test.

\section{Isolation yeast of sugar palm sap}

Palm sugar samples were obtained from several regions in West Sumatra. Isolation of sugar palm yeast is done by pour plate using a multilevel dilution method using the YEA medium.

\section{Isolation of yeast palm sugar}

\section{Morphological characterization of yeast isolates}

\section{Macroscopic characters}

Yeast isolates were observed based on the forms of the colony (circular, irregular, spindle filamentous, rhizoid); margins of colony (entire, lobate, undulate, serrate, filamentous); elevation of the colony (flat, raised, convex, umbonate) and color of the colony. As a guide, Cappuccino and Sherman (2005) and Kurtzman, Fell, Boekhout and Robert (2011) are used for identification.

\section{Microscopic characters}

Yeast isolates were observed on the slide under a microscope using a magnification of 10x100. Observations included cell shape, vegetative reproduction type, and cell generative reproduction type. As a guide, Smith and Yarrow in Samson and ReenenHoekstra (1988), Kurtzman and Fell (1998) and Kurtzman et al., (2011) are used for identification.

\section{Fermentation test of yeast isolates by in- vitro}

The fermentation test was carried out on an aerobic basis using the Durham tube on the fermentation media. This is seen from the formation of gas $\left(\mathrm{CO}_{2}\right)$ in the Durham tube due to the activity of yeast which has fermented glucose. $\mathrm{CO}_{2}$ that has been collected will then push the Durham tube up to the surface of the fermentation media. Yeast isolates are then ranked according to the speed of the Durham tube that appears on the surface of the media. Yeast isolates with the fastest Durham tube up to the surface were the isolates with the highest fermentation activity.

\section{Results and Discussion}

\section{Isolation yeast of sugar palm sap}

Yeast and microbes are believed to have carried out activities on fresh sugar palm sap that has been accommodated in containers in bunches. Based on direct surveys that have been carried out in the field, farmers take 
sugar palm sap twice a day, morning and evening. This is done by hanging the container in the male bunches. Empty containers are brought with each change of time. When palm sugar is accommodated in a container, indigenous microflora including yeast is believed to have been present and active on fresh sugar palm sap.

This is evidenced by the presence of microbes found in fresh sugar palm sap and can be seen in the GPA (Glucose Peptone Agar) medium. Not only that, yeast was also found in the medium of YEA (Yeast Extract Agar). As it has been revealed by Periadnadi, Sari and Nurmiati (2018) that the GPA medium is used to calculate the total microbes in general, especially sugar-based samples.

The existence of fresh sugar palm sap microbe on GPA medium and the existence yeast on YEA medium can be seen in Figure 1.

Based on the isolation of yeast on fresh sugar palm sap which has been carried out using the YEA medium, 11 isolates were obtained from the several samples of the sugar palm sap. The isolates were selected based on the size and visually differentiated morphology of the colonies that appeared on agar.

\section{Morphological character of yeast-isolates (Macroscopic and Microscopic)}

Macroscopic characters can be distinguished by seeing the differences in each colony that appear on the surface of the medium visually. Macroscopic characters include colony shape, colony edge, colony elevation, and colony color. The following is a picture of each yeast isolate colony of several regions in West Sumatra:

Based on macroscopic observations visually on colonies of yeast isolates, found differences in morphological characters in each isolate.
Macroscopic observation is an initial step that must be done before proceeding to microscopic observation so that yeast isolates can be identified and taxonomically distinguished. As stated by Cappuccino and Sherman (2005) when growing on various media, microbes will show macroscopic differences during their growth. This difference is called the difference in characteristics used as a basis for separating microbes into taxonomic groups.

The microscopic character of yeast isolates can be distinguished based on the shape of vegetative cells and the type of reproduction of yeast cells both vegetatively and generatively at the magnification of the microscope 10x100 with the help of immersion oil. Vegetatively or asexually, the type of yeast reproduction can be observed in pure isolates that are young, aged around 2448 hours while sexually, the type of yeast reproduction can be observed in isolates that have been aged for more than 7 days. As revealed by Smith and Yarrow in Samson and Reenen-Hoekstra (1988) that the type of yeast vegetative reproduction can be observed in young cultures, around 24-48 hours old while the type of yeast sexual reproduction can be observed in cultures that are 7-14 days old.

Based on the table 1, it can be seen that the morphological characters that appear in the yeast colonies macroscopically are following the characters stated by Cappuccino and Sherman (2005) that the yeast colonies on the media can be circular and irregular. The edge of the yeast colony can be in the form of undulate, serrate, entire, lobate and filamentous. Colony elevation can be in the form of raised, convex, flat and umbonate. Microscopically the characteristics of yeast isolates are following the characters stated by Kurtzman, Fell, Boekhout and Robert (2011) that vegetatively, yeast can reproduce by budding and multilateral budding. This is also 
consistent with the characteristics stated by Smith and Yarrow in Samson and ReenenHoekstra (1988) that generatively, yeast reproduces with unconjugated ascus with ascospore and ascus formed by mother-bud conjugation. The majority of yeasts, however, produce growth which ranges in color from white through cream to tan (Kurtzman et al., 2011) (Fig. 2-4).

Table.1 Description of morphological characteristics yeast isolates

\begin{tabular}{|c|c|c|c|c|c|c|}
\hline \multirow{2}{*}{$\begin{array}{l}\text { Isolate } \\
\text { Code }\end{array}$} & \multicolumn{4}{|c|}{ Macroscopis } & \multirow{2}{*}{$\begin{array}{c}\text { Vegetative } \\
\text { Reproduction }\end{array}$} & \multirow{2}{*}{$\begin{array}{c}\text { Generative } \\
\text { Reproduction }\end{array}$} \\
\hline & Form & Edge & Elevation & Colour & & \\
\hline $\mathbf{P Y B}_{1}$ & Circular & Undulate & Raised & white & budding & $\begin{array}{l}\text { unconjugated } \\
\text { ascuss with } \\
\text { ascospore }\end{array}$ \\
\hline $\mathbf{P Y B}_{2}$ & Circular & Undulate & Raised & cream & $\begin{array}{l}\text { multilateral } \\
\text { budding }\end{array}$ & $\begin{array}{l}\text { ascus formed by } \\
\text { mother-bud } \\
\text { conjugation }\end{array}$ \\
\hline $\mathbf{P Y B}_{3}$ & Circular & Serate & Raised & cream & $\begin{array}{l}\text { multilateral } \\
\text { budding }\end{array}$ & $\begin{array}{l}\text { ascus formed by } \\
\text { mother-bud } \\
\text { conjugation }\end{array}$ \\
\hline $\mathbf{P S T}_{4}$ & Circular & Entire & Convex & cream & $\begin{array}{l}\text { multilateral } \\
\text { budding }\end{array}$ & $\begin{array}{l}\text { ascus formed by } \\
\text { mother-bud } \\
\text { conjugation }\end{array}$ \\
\hline $\mathbf{P S T}_{5}$ & Circular & Entire & Raised & cream & $\begin{array}{l}\text { multilateral } \\
\text { budding }\end{array}$ & $\begin{array}{l}\text { unconjugated } \\
\text { ascuss with } \\
\text { ascospore }\end{array}$ \\
\hline PLB $_{6}$ & Ireguler & Lobate & Raised & cream & $\begin{array}{l}\text { multilateral } \\
\text { budding }\end{array}$ & $\begin{array}{l}\text { unconjugated } \\
\text { ascuss with } \\
\text { ascospore }\end{array}$ \\
\hline $\mathbf{P L B}_{7}$ & Circular & Entire & Flat & brown & budding & $\begin{array}{l}\text { ascus formed by } \\
\text { mother-bud } \\
\text { conjugation }\end{array}$ \\
\hline $\mathbf{P L B}_{8}$ & Circular & Filamentous & Flat & cream & budding & $\begin{array}{l}\text { ascus formed by } \\
\text { mother-bud } \\
\text { conjugation }\end{array}$ \\
\hline BTS $_{9}$ & Ireguler & Undulate & Umbonate & cream & $\begin{array}{l}\text { multilateral } \\
\text { budding }\end{array}$ & $\begin{array}{l}\text { unconjugated } \\
\text { ascuss with } \\
\text { ascospore }\end{array}$ \\
\hline BTS $_{10}$ & Circular & Entire & Raised & cream & budding & $\begin{array}{l}\text { ascus formed by } \\
\text { mother-bud } \\
\text { conjugation }\end{array}$ \\
\hline BTS $_{11}$ & Circular & Entire & Raised & cream & $\begin{array}{l}\text { multilateral } \\
\text { budding }\end{array}$ & $\begin{array}{l}\text { unconjugated } \\
\text { ascuss with } \\
\text { ascospore }\end{array}$ \\
\hline
\end{tabular}


Table.2 The isolate ranking is based on the fermentation test using a Durham tube

\begin{tabular}{|c|c|}
\hline Isolate & Ranking \\
\hline PYB $_{\mathbf{1}}$ & 4 \\
\hline PYB $_{\mathbf{2}}$ & 11 \\
\hline PYB $_{\mathbf{3}}$ & 10 \\
\hline PST $_{\mathbf{4}}$ & 5 \\
\hline PST $_{\mathbf{5}}$ & 7 \\
\hline PLB $_{\mathbf{6}}$ & 8 \\
\hline PLB $_{\mathbf{7}}$ & 2 \\
\hline PLB $_{\mathbf{8}}$ & 3 \\
\hline BTS $_{\mathbf{9}}$ & $\mathbf{1}$ \\
\hline BTS $_{\mathbf{1 0}}$ & 9 \\
\hline BTS $_{\mathbf{1 1}}$ & 6 \\
\hline
\end{tabular}

Fig.1 (a) The existence of microbe on GPA medium (b) The existence of yeast on YEA medium
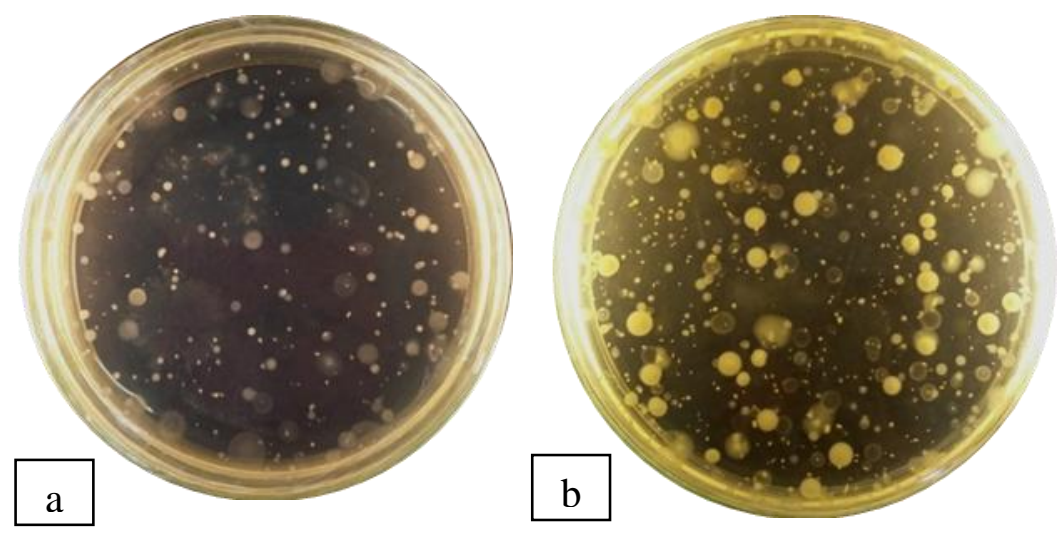

Fig.2 Colonies yeast isolates of fresh sugar palm sap on YEA medium (PYB: Payakumbuh; PST: East Pasaman; PLB: Palembayan; BTS: Batusangkar)
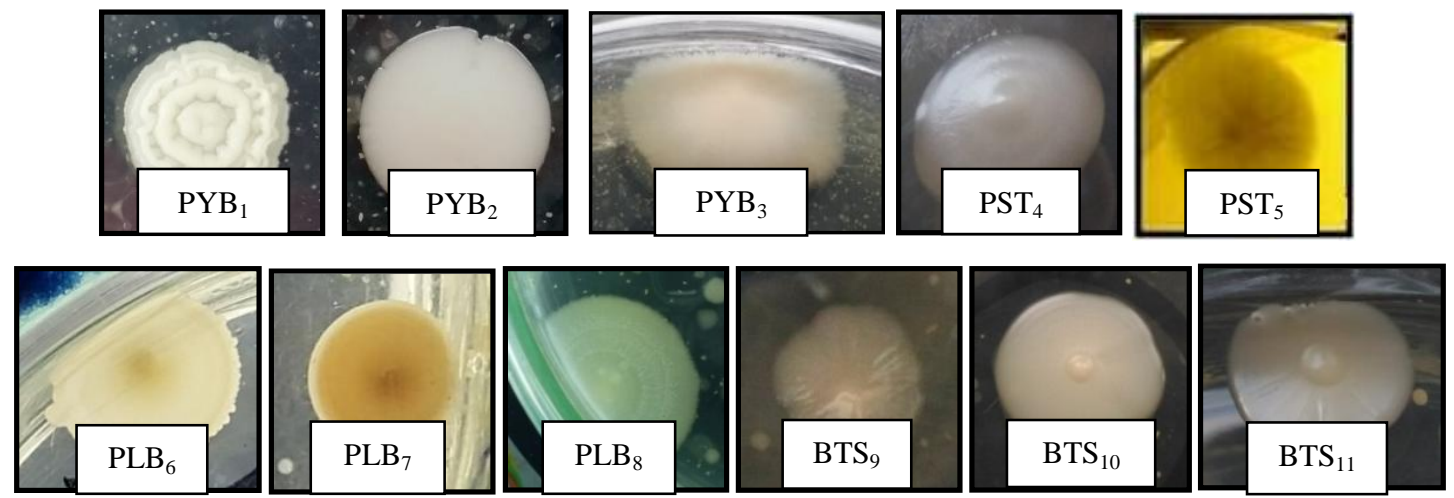
Fig.3 (a) Yeast isolat colony, (b) generative reproduction (sexual) and (c) vegetative reproduction (asexual); 1-3: isolate $\mathrm{PYB}_{1-3}$; 4-5: isolate $\mathrm{PST}_{4-5}$; 6-8: isolate $\mathrm{PLB}_{6-8}$; 9-11: isolate

BTS $_{9-11}$

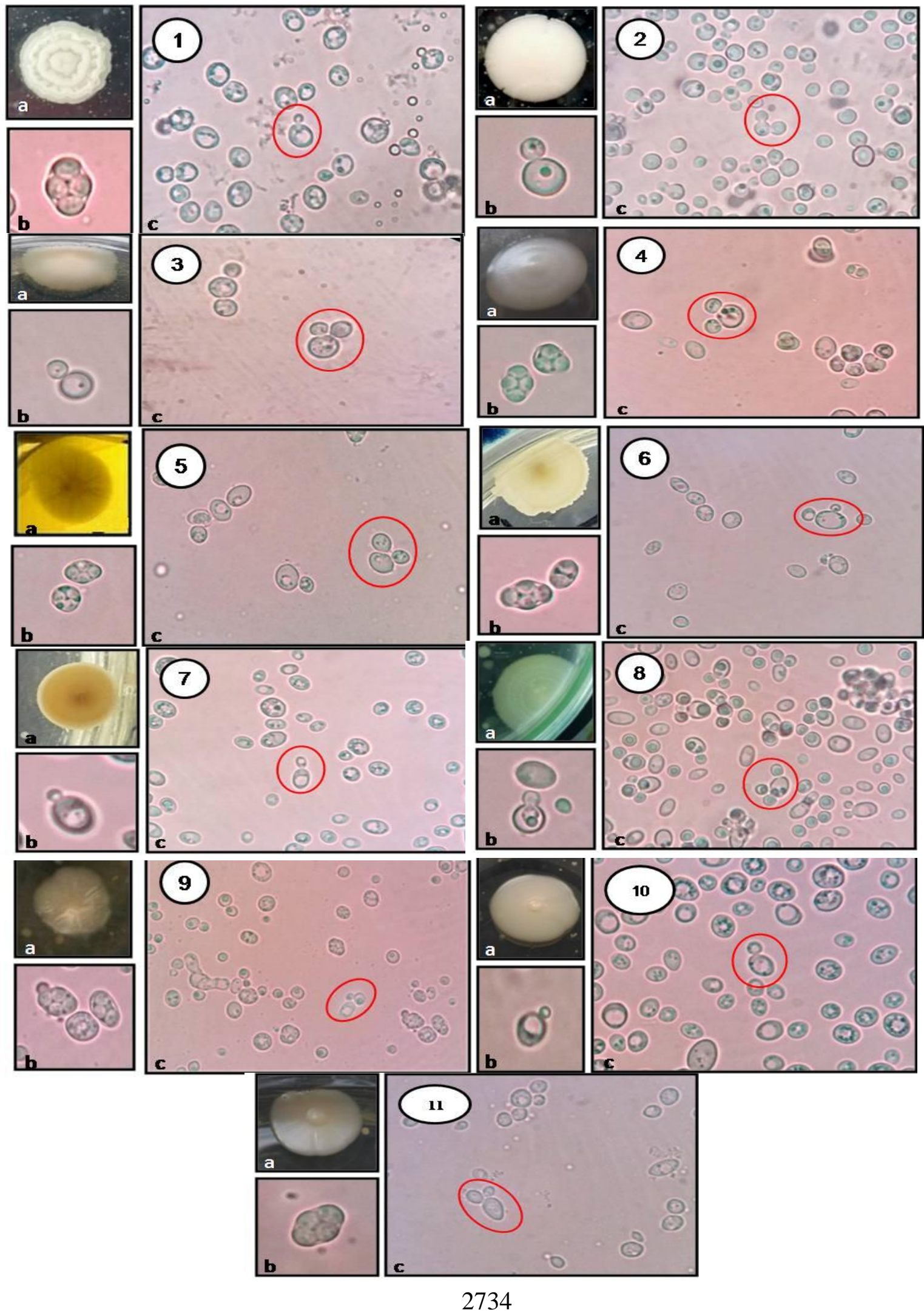


Fig.4 Potential character of yeast isolates by fermentation test using Durham tubes; (a) Gas $\left(\mathrm{CO}_{2}\right)$ formed, (b) The Durham tube has up to the surface

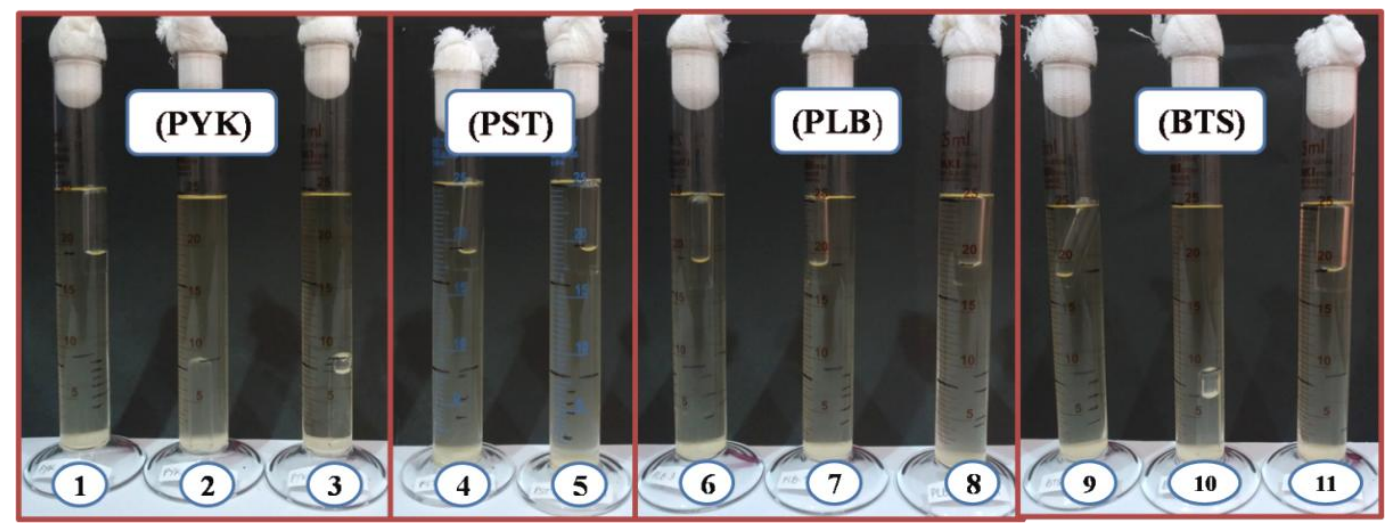

Asexual reproduction, sometimes erroneously termed vegetative reproduction, occurs in yeasts by budding, by fission, and by the production of forcefully ejected ballistoconidia on stalks termed sterigmata (Kurtzman et al., 2011).

Budding is also classified in terms of the position of the site where it occurs. Budding that is restricted to one pole of the cell is termed monopolar, and budding that occurs at both poles of the cell is termed bipolar. Budding from various sites on the cell is termed multilateral or multipolar. When the buds are abstricted on a rather broad base by the formation of a cross wall, the process is referred to as "budding on a broad base" and "bud fission" (Streiblová 197 in Kurtzman et al., 2011). Cells can be globose, subglobose, ellipsoid, ovoid, obovoid, cylindrical, botuliform, bacilliform, elongate, apiculate, ogival, lunate, or triangular (Kurtzman et al., 2011).

In addition vegetative reproduction, some yeasts are able to reproduce sexually. Most do so by means of ascospore in ascus (ascomycetous yeasts). There different processes of ascus formation exist. The ascus can be formed by direct transformation of a vegetatif cell (unconjugated ascus), by mother-bud conjugation or by conjugation between independent single cells. Ascospore are produced in the ascus. The structure and shape of the ascospore varies. They may be smooth or rough, they can be spherical, hatshaped and reniform (Smith and Yarrow in Samson and Reenen-Hoekstra, 1988).

\section{Potential character of yeast isolates by fermentation test}

The fermentative potential character is carried out on yeast isolates through fermentation test using Durham tubes which an aerobic basis. The fermentation media used is glucose $10 \%$ as a carbon source with the addition of nutrients $1 \mathrm{~g} / \mathrm{L}$ yeast extract. These results become a reference for determining the most potential yeast isolates among all isolates based on whether or not Durham tubes up to the surface.

Yeast isolates will be ranked base on the formation of gas $\left(\mathrm{CO}_{2}\right)$ in the Durham tube due to the activity of yeast that has converted glucose. The gas $\left(\mathrm{CO}_{2}\right)$ formed will then be trapped inside the Durham tube so that the volume of gas will push the Durham tube up to the surface of the media. Following the stated by Smith and Yarrow in Samson and Reenen-Hoekstra (1988) that fermentation is detected by examining the Durham tube to determine the presence of gas for several 
periods. The same thing has been reported by Okagbue (1988) that the isolated yeast is then screened to see fermentation activities using Durham tubes. After incubating at room temperature for 48 hours the presence of gas was taken as evidence of a reasonably high rate of fermentation activity.

As Sari (2017) and Rahmah (2018) have done, the fermentation test using a Durham tube was carried out to see how the potential of yeast isolates was obtained based on the speed of the isolate in converting its substrate marked by the presence of gas in the Durham tube.

Based on the picture above, it can be seen that there is gas in the Durham tube as a result of the substrate overhaul process carried out by each yeast isolate. The following are the results of the fermentation test of yeast isolates which can be seen in the table 2 .

Based on the table 2: among all isolates, BTS $_{9}$ isolates were isolated that had high fermentation activity. This is characterized by a fast fermentation process so that gas is also quickly formed. The formation of gas will then push the Durham tube faster to the surface of the media. This shows that BTS $_{9}$ isolates have greater potential in the fermentation process. As we know, the product of fermentation is ethanol. The more gas that is formed, the more ethanol will be produced. This indicates that $\mathrm{BTS}_{9}$ isolates have more potential in producing ethanol. In line with the statement of Rahmana et al., (2016) that yeast has very good potential in converting glucose to ethanol

Based on the research that has been done, it can be concluded as follows

1. 11 yeast isolates were found with different macroscopic and microscopic characters from several samples of fresh sugar palm sap.

2. In the character of fermentative potential, $\mathrm{BTS}_{9}$ isolate is the yeast that has the highest fermentation activity.

\section{References}

Cappuccino, J.G and Sherman, N. 2005. Microbiology: a Laboratory Manual, Seventh Edition. Pearson Education, Inc. San Fransisco.

Effendi, D.S. 2010. Prospek Pengembangan Tanaman Aren (Arenga pinnata Merr) Mendukung Kebutuhan Bioethanol di Indonesia. ISSN: 1412-8004 Perspektif 9 (1): 36-46

Kurtzman, C.P. and J.W. Fell. 1998. The Yeast, a Taxonomic Study. Elsevier. Netherlands

Kurtzman, C.P., J.W. Fell, T. Boekhout and V. Robert. 2011. The Yeast, a Taxonomic Study. Elsevier. Netherlands

Okagbue, R.N. 1988. A Note on The Leavening Activity of Activity of Yeasts Isolated From Nigerian Palm Wine. Journal of Applied Bacteriology. 64: 235-239

Periadnadi, D.K. Sari and Nurmiati. 2018. Isolasi dan Keberadaan Khamir Potensial Pemfermentasi Nira Aren (Arenga pinnata Merr.) dari Dataran Rendah dan Dataran Tinggi di Sumatera Barat. Bioeksperimen 4 (1) : 29-36

Rahmah, S.A. 2018. Skrining Khamir Potensial Penghasil Alkohol Dari Air TApai Dalam Pencarian Isolat Unggul Produksi Bioetanol dari Ubi Kayu (Manihot utilissima Pohl.). Undergraduated Biology Thesis. Andalas University: Padang

Rahmana, S. F., S. Nurhatika and A. Muhibuddin. 2016. Uji Potensi Fermentasi Etanol Beberapa Yeast yang Diisolasi dari Daerah Malang, Jawa Timur dengan Metode SDN (Soil Drive Nutrient). JURNAL SAINS DAN SENI ITS. 5 (2): 47-52

Samson, R.A dan E. S. van R-Hoekstra. 1998. Introduction to Food Borne Fungi. 
Centraal bureau voor Schimmel cultures AG.BAARN. The Netherlands.

Sari, D. K. 2017. Isolasi dan Keberadaan Khamir Potensial Pemfermentasi Nira Aren (Arenga pinnata Merr.) Dari Dataran Rendah dan Dataran Tinggi di Sumatera Barat. Undergraduated Thesis Biology. Andalas University. Padang
Satyanarayana and G. Kunz. 2009. Yeast Biotechnology:Diversity and Applications. Springer Science + Business Media B.V. New Delhi and Jerman

Schneiter, R. 2004. Genetics, Molecular and Cell Biology of Yeast. Universität Freiburg Schweiz. Swiss.

\section{How to cite this article:}

Primadona Raesa Putri, Nurmiati Nurmiati dan Periadnadi Periadnadi. 2019. Screening of Potential Yeast of Sugar Palm Sap from Several Regions of West, Sumatra to Find Superior Isolate for Support Bioethanol Production. Int.J.Curr.Microbiol.App.Sci. 8(12): 2729-2737.

doi: https://doi.org/10.20546/ijcmas.2019.812.319 